DOI: 10.32089/WBH.PHW.2020.4(274).0004

orcid.org/0000-0001-5856-7016

ARTuR OCHAt

(Archiwum Straży Granicznej z siedzibą w Szczecinie)

\title{
Bohaterski czyn por. Kazimierza Śledzińskiego podczas napadu pod Sieniawką (1926 r.). Przyczynek do historii Korpusu Ochrony Pogranicza (1924-1939)
}

Głównym zadaniem Korpusu Ochrony Pogranicza (KOP) jako specjalnej formacji wojskowej, utworzonej w $1924 \mathrm{r}$. dla ochrony granic wschodnich II Rzeczypospolitej Polskiej było przywrócenie ładu, porządku i bezpieczeństwa na pograniczu. Żołnierze KOP mieli zabezpieczać granicę państwa i chronić mieszkającą tam ludność przed radziecką dywersją i pospolitym bandytyzmem, gdyż pomimo podpisania traktatu ryskiego (21 marca 1921 r.), formalnie kończącego wojnę polsko-rosyjską (1918-1921)1, Kresy Wschodnie II Rzeczypospolitej nadal nie były miejscem bezpiecznym dla mieszkańców. Wprawdzie Rosja Radziecka oficjalnie uznała postanowienia traktatu pokojowego i ratyfikowała je, tym samym uznając m.in. kształt i przebieg granicy z Polską, ale komuniści z Kominternu (ros. Коммунистический интернационал) $)^{2}$ nigdy nie zarzucili swoich planów światowej rewolucji,

\footnotetext{
${ }^{1}$ Autor podziela pogląd prof. Karola Olejnika, że była to wojna z Rosją, nie z bolszewikami, gdyż nie każdy żołnierz Armii Czerwonej był bolszewikiem, ale był obywatelem Rosji. Wprawdzie była to Rosja „czerwona”, która zastąpiła „białą” (carską), ale nadal była to Rosja $\mathrm{z}$ takimi samymi dążeniami imperialnymi, tylko pod innymi rządami i zmienionymi hasłami. Podzielając ten pogląd, autor stosuje w pracy pojęcie wojna polsko-rosyjska (1918-1921). Zob. K. Olejnik, „Recenzja dysertacji doktorskiej: Artur Ochał, Brygada Korpusu Ochrony Pogranicza «Grodno» w latach 1929-1939 Szczecin, 2012", Kołobrzeg 4 IV 2012 r., mps.

${ }^{2}$ Komintern - skrót od Kommunisticzeskij internacyonał - Międzynarodówka Komunistyczna (dlatego także nazywany był III Międzynarodówką). Organizacja międzynarodowa, która powstała z inicjatywy Włodzimierza Lenina w Moskwie w 1919 r. Utworzona została przez 19 partii komunistycznych, w tym Komunistyczną Partię Polski. Celem Kominternu było propagowanie idei komunistycznych i prowadzenie przygotowań do światowej rewolucji.
} 
tj. przeniesienia komunizmu m.in. do krajów Europy Zachodniej. Główną przeszkodą nadal pozostawała Polska, a pierwszą barierą była granica, chroniona początkowo przez nieprzygotowane i stosunkowo nieliczne jednostki wojskowe (Bataliony Celne, Bataliony Straży Granicznej3), a od lipca 1923 r. przez graniczne oddziały Policji Państwowej. To dlatego wschodnie pogranicze i mieszkająca tam ludność stały się celem ataków grup dywersyjnych i pospolitych band rabunkowych, a działania inspirowane przez radziecki wywiad wojskowy miały prowadzić do destabilizacji sytuacji i sterroryzowania mieszkańców. Celem napadów stały się polskie zaścianki, miejscowe dwory, plebanie, posterunki policji, a nawet kresowe miasteczka (m.in. Wiszniew, Stołpce, Łowcza). Rabowano ludność, pozbawiano ją dobytku i żywego inwentarza, dochodziło do gwałtów i zabójstw. Szczególnie zagrożone były osady położone wzdłuż linii granicy, gdyż w większości przypadków, bandy dywersyjne po dokonanych atakach wycofywały się na radzieckie terytorium. Według wyliczeń historyków w okresie od ratyfikowania traktatu pokojowego do kwietnia 1924 r. na Kresach Wschodnich odnotowano 259 bandyckich napadów przeprowadzonych lub inspirowanych z terenu Rosji Radzieckiej (od 1922 r. Związku Radzieckiego) ${ }^{4}$. Skala i rozmach ataków

Założenia programowe zob. S. Sierpowski, Źródła do historii powszechnej okresu międzywojennego, 1917-1926, Poznań 1989, s. 87-93.

${ }^{3}$ Bataliony Celne (1921-1922) utworzone zostały w kwietniu 1921 r. z wojskowych batalionów wartowniczych i etapowych, które wcześniej pełniły służbę na granicach. Formacja umundurowana była w mundury Wojska Polskiego i pozostawała na zaopatrzeniu armii. Pod względem służbowym podlegała pod Ministerstwo Skarbu, które odpowiedzialne było za ochronę celno-gospodarczą państwa, ale pod względem wojskowym podporządkowana była Ministerstwu Spraw Wojskowych (MSWojsk.). Bataliony Celne dowodzone były kolejno przez: płk. kaw. Bronisława Januarego Zaniewskiego, gen. bryg. Maksymiliana Lindę i płk. żand. Władysława Jaksę-Rożena. Od maja 1922 r. podlegały pod względem służbowym Ministerstwu Spraw Wewnętrznych. W listopadzie 1922 r. zostały przeorganizowane w Straż Graniczną (1922-1923) pod dowództwem płk. żand. Jaksy-Rożena. Ochraniały granicę: polsko-łotewską, polsko-radziecką i część polsko-rumuńskiej. W lutym 1923 r. bataliony Straży Granicznej w ramach grupy płk. Stefana Pasławskiego wzięły udział w zajęciu polskiej części pasa neutralnego i objęły ochronę linii granicznej z Litwą. Straż była formacją złożoną z oddziałów pieszych i konnych, zorganizowanych na wzór wojskowy, przy czym umundurowanie żołnierzy różniło się od wojskowego jedynie jasnozielonymi patkami z białymi wypustkami na kołnierzach mundurów i płaszczy. Ze względu na konieczność zdemobilizowania znacznej części żołnierzy formacja została zlikwidowana z końcem października 1923 r. Od 1 VII 1923 r. ochronę granicy przejęła Policja Państwowa. Zob. H. Dominiczak, Granice państwa i ich ochrona na przestrzeni dziejów 966-1996, Warszawa 1997, s. 242-249.

${ }^{4}$ Według obliczeń kpt. Bazylego Rogowskiego z Wywiadu KOP, tylko w 1924 r. miało miejsce 189 napadów bandycko-dywersyjnych oraz 28 aktów sabotażu. Andrzej Pepłoński ustala liczbę wypadków bandyckich inspirowanych przez ZSRR na 259, a Andrzej Ajnenkiel szacuje ich liczbę na ok. 200. Zob. B. Rogowski, Działalność KOP w Świetle cyfr, Korpus Ochrony Pogranicza w trzecią rocznicę objęcia służby na granicach Rzeczypospolitej 1926-1927, red. F. Jamka-Koperski, Warszawa [1927], s. 11; A. Pepłoński, Wywiad Polski 
radzieckiej dywersji z lat 1923-1924 sprawiły, że Prezydent i Rada Ministrów zdecydowali się na radykalne rozwiązanie, jakim było utworzenie jesienią 1924 r. Korpusu Ochrony Pogranicza - specjalnej formacji wojskowej dla ochrony granicy wschodniej II Rzeczypospolitej. W początkowym okresie zakładano, że zadaniem formacji w czasie pokoju będzie ochrona granicy i bezpieczeństwa na pograniczu, a w razie działań wojennych współdziałanie z wojskiem w osłonie mobilizacji i koncentracji armii. Dopiero po opanowaniu sytuacji na wschodnim pograniczu sprecyzowano, że do głównych zadań KOP należeć miało m.in.: zabezpieczenie znaków i urządzeń granicznych przed celowym lub przypadkowym zniszczeniem; zabezpieczenie dochodów państwa z tytułu opłat celnych (ochrona celna); zapobieganie nielegalnemu przekraczaniu granicy przez przedstawicieli lub organy obcych państw oraz przez osoby nieuprawnione; zapobieganie przenoszeniu antypolskich druków; ściganie wrogiej i antypaństwowej działalności, a także walka z rozprzestrzenianiem się chorób zakaźnych i ochrona granicy pod względem wojskowym w dziedzinie obrony państwa.

Jednostki KOP tworzone w latach 1924-1927 zostały zgrupowane w trzech rzutach: pierwszą linię ochrony tworzyły strażnice i posterunki przejściowe (bez stałej obsady), rozmieszczone wzdłuż linii granicy. Strażnice były podstawą systemu ochrony pogranicza, a ich obsadę stanowiło zazwyczaj 18 żołnierzy pod dowództwem doświadczonego podoficera. W drugiej linii ochrony znajdowały się dowództwa kompanii granicznych oraz odwody kompanijne w sile plutonu. Trzecią linię stanowiły odwody batalionowe (początkowo plutony ciężkich karabinów maszynowych - ckm i kompanie szkolne) rozlokowane przy dowództwach batalionów oraz szwadrony kawalerii KOP, które spełniały rolę mobilnych odwodów formacji. Bataliony i szwadrony KOP wchodziły w skład brygad (później także pułków), które podlegały dowództwu formacji w Warszawie. KOP w okresie swojego istnienia był kilkakrotnie reorganizowany, a jego struktura dostosowywana była do nowych zadań stawianych przed formacją na czas pokoju i działań wojennych. Strefą działania formacji był pas pogranicza wschodniego o głębokości do $30 \mathrm{~km}$. Przyjęte ugrupowanie jednostek KOP, a przede wszystkim determinacja żołnierzy w zwalczaniu dywersji i pospolitego bandytyzmu, miały doprowadzić do uspokojenia pogranicza polsko-radzieckiego.

Twórca i pierwszy dowódca Korpusu Ochrony Pogranicza gen. dyw. Henryk Odrowąż-Minkiewicz w pierwszym rozkazie skierowanym do swoich żołnierzy napisał:

na ZSRR 1921-1939, Warszawa 1996, s. 66; A. Ajnenkiel, Geneza KOP - uwarunkowania polityczne [w:] Korpus Ochrony Pogranicza w 70 rocznicę powołania, red. L. Grochowski, Kętrzyn 1994, s. 29; P. Skubisz, „Wileńska Brygada Korpusu Ochrony Pogranicza w latach 1924-1937”, Szczecin 2008, s. 29, mps. 
„powołani zostaliście do szeregów Korpusu, aby pełnić ciężką i odpowiedzialną służbę ochrony wschodniej granicy Rzeczypospolitej. Czeka Was zadanie trudne, wymagające żołnierskiego poświęcenia, hartu woli i siły charakteru. Oto zbrojne najemne bandy wkraczają w granice Państwa Polskiego, aby palić dobytek spokojnym mieszkańcom, grabić ich mienie, mordować opornych, a następnie ratować się ucieczką, zostawiając za sobą zgliszcza i ruiny. Na ziemiach umęczonych długoletnią wojną, zapanował znowuż gwałt i terror. [...] W tych warunkach cała ludność województw kresowych spogląda na żołnierzy KOP, jako na swoich właściwych obrońców [...] Wasze imię żołnierza Korpusu powołanego do ochrony granic musi być z ufnością i szacunkiem wymawiane przez całą ludność, a jednocześnie musi być postrachem dla zbrojnych bandytów. Nigdy przed zbrojną bandą żołnierz Korpusu nie ustąpi, nigdy się nie cofnie. Żołnierze znamionować Was musi odwaga i bitność, męstwo i pogarda śmierci. Zawsze naprzód! Atakować i ścigać do upadłego"5.

Oddziały KOP już pod koniec października 1924 r. przystąpiły do obejmowania granicy polsko-radzieckiej i niemal z marszu weszły do walki z dywersją i pospolitym bandytyzmem. Tylko w listopadzie i grudniu $1924 \mathrm{r}$. żołnierze KOP odparli ogniem posterunków i zasadzek 39 prób wdarcia się na polskie terytorium grup dywersyjnych i pospolitych band. W 1925 r. było już tylko 50 prób napadów dokonanych na pograniczu. W pierwszym roku istnienia formacji wytropiono 51 band lub organizacji dywersyjno-bandyckich działających na pograniczu, z tego 25 zostało spłoszonych i uciekło za granicę. Podczas działań zabito 22 osoby, zraniono 18, a 79 bandytów ujęto i osadzono w więzieniach. W 1926 r. na odcinku ochrony KOP wytropiono kolejne 22 bandy, spłoszono za granicę 6 . Podczas walki z bandytami zabito 10 osób, 4 następne zostały zranione, a kolejnych 31 ujęto i osadzono w więzieniach. Ponadto zatrzymano 294 osoby podejrzane o udział w napadach. Jak niebezpieczna była to służba, niech świadczy fakt, że w 1926 r. co najmniej 70 razy zza radzieckiej granicy padły strzały w kierunku żołnierzy KOP pełniących służbę na pograniczu. Od ran i chorób nabytych podczas służby w ciężkich warunkach w okresie od 1 listopada 1925 do 1 września 1926 r. zmarło czterech oficerów i 66 szeregowych KOP ${ }^{6}$.

${ }^{5}$ Dokument nr 23, Rozkaz dzienny nr 1 dowódcy KOP gen. dyw. Henryka Minkiewicza, [Warszawa 23 X 1924 r.] [w:] O Niepodległa i granice, t. 4: Korpus Ochrony Pogranicza 1924-1939. Wybór dokumentów, wstęp M. Jabłonowski, wyb. i oprac. M. Jabłonowski et al., Warszawa-Pułtusk 2001, s. 47.

\footnotetext{
${ }^{6}$ Zestawienie statystyczne wypadków zaszłych na terenie 1-6 brygady Korpusu Ochrony Pogranicza za czas od 1 października 1926 r. do 1 listopada 1926 r.; Lista zmarlych w okresie od dnia 1 listopada 1925 r. do dnia 1 września 1926 r., Korpus Ochrony Pogranicza w druga rocznicę objęcia służby na granicach Rzeczypospolitej 1925-1926, Warszawa 1926, s. I-II;
} 
Jednym z żołnierzy, którzy w 1924 r. stanęli do walki w obronie bezpieczeństwa Kresów Wschodnich II Rzeczypospolitej Polskiej, był ppor. Kazimierz Śledziński II, a jego czyn jako oficera 9 Batalionu $\mathrm{KOP}^{7}$ w Klecku to przykład okazanej odwagi i męstwa żołnierza Korpusu Ochrony Pogranicza. Pomny słów rozkazu gen. Minkiewicza, w poczuciu żołnierskiego obowiązku, w 1926 r. w pojedynkę stoczył walkę w obronie osób cywilnych podróżujących autobusem pod Sieniawką koło Nieświeża na Nowogródczyźnie. To właśnie jemu jako pierwszemu nadano Krzyż Zasługi za Dzielność - najważniejsze odznaczenie nadawane żołnierzom i funkcjonariuszom II Rzeczypospolitej za odwagę wykazaną w okresie pokoju.

Kazimierz Śledziński urodził się w 1902 r. w Stanisławowie (pow. Zaleszczyki), w rodzinie Kacpra i Wincentyny z Urbańskich. Uczył się w szkole powszechnej, a następnie rozpoczął naukę w państwowym gimnazjum w Podwołoczyskach. Kontynuował ją w państwowych szkołach realnych w Rawie Ruskiej i Stanisławowie, ale po rosyjskiej ofensywie w latach 19151916 kolejną klasę ukończył w Pradze czeskiej. Szóstą klasę znów rozpoczął w Stanisławowie, ale przerwał naukę ze względu na sytuację jaka panowała w 1918 r. w Galicji Wschodniej. Ze względu na walki polsko-ukraińskie wraz z rodziną znalazł się w Jarosławiu, gdzie kontynuował naukę. 19 lipca $1920 \mathrm{r}$. w trakcie wojny polsko-rosyjskiej (1918-1921), w czasie dramatycznego odwrotu wojsk polskich, jako 18-letni ochotnik wstąpił do 39 Pułku Piechoty (pp) Strzelców Lwowskich. Pułk, który poniósł dotkliwe straty w czasie rosyjskiej ofensywy, odbudowywał się w tym czasie w Jarosławiu, gdzie Śledziński zgłosił się do służby. W połowie sierpnia 1920 r. jego kompania została w całości przeniesiona jako uzupełnienie do łomżyńskiego 33 pp, który

Zestawienie statystyczne wypadków zaszłych na terenie 1-6 brygady Korpusu Ochrony Pogranicza za czas od 1 listopada 1926 r. do 1 listopada 1927 r., Korpus Ochrony Pogranicza w trzecia rocznice objęcia służby na granicach Rzeczypospolitej 1926-1927, Warszawa 1927, s. 13.

${ }^{7}$ Zgodnie z rozkazem gen. dyw. H. Minkiewicza z 1926 r. wszystkim jednostkom KOP nadane zostały porządkowe numery arabskie: brygadom (od 1 do 6), batalionom (od 1 do 29) i szwadronom (od 1 do 20). Nazwa jednostki podawana była z podaniem miejsca stacjonowania dowództwa, np. 24 Batalion KOP w Sejnach. Kompanie graniczne nosiły numery arabskie, jedynie plutony w kompaniach i szwadronach kawalerii oznaczano cyframi rzymskimi. Plutony łączności i ckm były bez numerów. W październiku 1930 r., zgodnie z poleceniem dowódcy KOP, dla wszystkich jednostek formacji przyjęta została zasada nadawania nazwy miejsc lub regionów ich stacjonowania, np. Batalion KOP „Orany”. Nazwy jednostek urzędowo pisane były w cudzysłowie, bez dotychczasowej numeracji. Nazwy miejscowości brano z map Wojskowego Instytutu Geograficznego, wobec czego nie zawsze pokrywały się z nazwami ogólnie używanymi. Zob. Archiwum Straży Granicznej w Szczecinie (dalej: ASGr), Dowództwo KOP, sygn. 177/12, Rozkaz nr 19, Warszawa 22 II 1926 r., k. 57; sygn. 177/16, Rozkaz nr 43, Warszawa 11 X 1930 r., k 264-271; sygn. 177/39, Rozkaz tajny nr 11, Warszawa 8 IV 1931 r., k. 17-18; sygn. 177/69, Rozkaz wewnętrzny nr 21, Warszawa 30 IV 1931 r., k. 39-40; sygn. 177/49, Rozkaz tajny nr 10, Warszawa 14 III 1936 r., k. 50-62. 
poniósł znaczne straty w walkach pod Osowem. Śledziński jako szeregowy brał udział w walkach 1/I batalionu $33 \mathrm{pp}$ m.in. w obronie Warszawy oraz na froncie południowo-wschodnim w Małopolsce Wschodniej, m.in. nad Gniłą Lipą, w bojach o Kozów, Słobodę, Złotą Strykę, Seret, Tarnopol, Zbaraż, Zasław, dochodząc wraz z pułkiem, we wrześniu, do rzeki Słuczy ${ }^{8}$. Mimo młodego wieku wyróżniał się jako dzielny i ofiarny żołnierz. Po zakończeniu ofensywy 6 Armii WP, w trakcie zawieszenia broni, 13 listopada 1920 r. jako młodocianego zwolniono go z wojska, dając mu możliwość ukończenia nauki i uzyskania świadectwa dojrzałości w Jarosławiu. Po roku, już jako absolwent siedmioklasowej szkoły realnej w Jarosławiu, ze świadectwem dojrzałości, z początkiem września 1921 r. został ponownie przyjęty do Wojska Polskiego i przydzielony do 41 klasy Szkoły Podchorążych w Warszawie. Szybko awansował, dochodząc w lipcu 1922 r. do stopnia sierżanta podchorążego. Z początkiem lipca 1922 r. przyjęto go jako elewa do Oficerskiej Szkoły Piechoty przy Szkole Podchorążych WP, którą po roku ukończył w stopniu ppor. Warto wspomnieć, że w opinii o nim odnotowano m.in.: „najbardziej nadaje

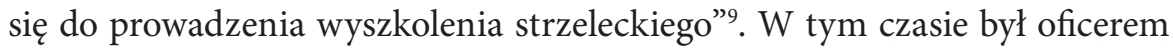
rezerwy w służbie czynnej. Jego pierwszym przydziałem był $10 \mathrm{pp}$ stacjonujący w Łowiczu. Po jego przybyciu do garnizonu (16 sierpnia 1923 r.) powierzono mu stanowisko dowódcy plutonu w 3 kompanii. Pod koniec czerwca udzielono mu pierwszego urlopu (do 12 lipca), po którym powrócił na dotychczasowe stanowisko dowódcy plutonu ${ }^{10}$. Warto $\mathrm{w}$ tym miejscu przytoczyć pierwszą opinię służbową oficerską, jaką wydał o nim w październiku 1923 r. płk Kazimierz Topoliński, ówczesny dowódca pułku: „młody, jeszcze nie wyrobiony charakter o dodatnich zaletach osobistych. Ambitny, chętny i pilny daje rękojmię, że z czasem wyrobi się na bardzo dobrego oficera. Dobry dowódca plutonu i instruktor"11. W kilka miesięcy po przybyciu do pułku, 19 listopada, został przemianowany na oficera zawodowego ${ }^{12}$. Podczas służby w łowickim

${ }^{8}$ J. Ciapka, Zarys historii wojennej 33-go pułku piechoty, Warszawa 1929, s. 29-30; Centralne Archiwum Wojskowe Wojskowego Biura Historycznego (dalej: CAW-WBH), Kolekcja akt personalnych i odznaczeniowych (dalej: AP), AP 12491, Śledziński Kazimierz, Curriculum vitae, Warszawa 21 X 1921 r., b.p.; Testimonium ortus et baptismi, b.m. 24 XI 1917 r.; Świadectwo dojrzałości, dr Jan Ralski, Jarosław 2 VII 1921 r., b.p.

${ }^{9}$ Ukończył z wynikiem zadawalającym z lokatą 60/126. Zob. CAW-WBH, AP 12491, Śledziński Kazimierz, Zaświadczenie z batalionu zapasowego 33 pp, Łowicz 8 XII 1920 r., b.p.; Wyciąg kwalifikacyjny ukończenia Oficerskiej Szkoły Piechoty, Warszawa 3 VII 1923 r., b.p.

${ }^{10}$ Ibidem, Odpis. Karta ewidencyjna por. Kazimierz Śledziński II, Łowicz 3 IX 1923 r. [1927 r.], b.p.

${ }^{11}$ Ibidem, Roczne uzupełnienie listy kwalifikacyjnej za rok 1923, 10 pp, Łowicz 24 X 1923 r., b.p.

${ }^{12}$ Służba zawodowa z dniem 1 XI 1923 r. na podstawie dekretu z 16 XI 1923 r., Dz. Pers. MSWojsk. 1923, nr 72. Starszeństwo w stopniu z 1 VII 1923 r. Zob. CAW-WBH, AP 12491, 
garnizonie uczył się i nabierał doświadczenia w dowodzeniu jako młodszy oficer kompanii, co zaowocowało czasowym powierzeniem mu - w zastępstwie nieobecnego dowódcy - dowództwa kompanii (22 lutego - 2 marca 1924 r.) $)^{13}$. Kolejne miesiące upływały na szkoleniu młodych żołnierzy w dowodzonym przez niego plutonie.

Jesienią 1924 r., w związku z pośpiesznym tworzeniem nowej formacji dla ochrony granicy wschodniej II Rzeczypospolitej Polskiej, ppor. Śledziński z dniem 9 października został przeniesiony do Korpusu Ochrony Pogranicza. Być może z patriotycznych pobudek sam zgłosił się do służby na wschodniej granicy i trafił do 2 Brygady KOP. Rozkazem nr 1/24 płk. Józefa Olszyny-Wilczyńskiego, ówczesnego dowódcy brygady, otrzymał przydział do 9 Batalionu KOP w Klecku. Ze względu na to, że w tym czasie Korpus był formacją nieewidencyjną, ppor. Śledziński pozostając na ewidencji oficerów w 10 pp, służbowo został przeniesiony do 79 pp stacjonującego w Słonimiu, gdzie tworzony był jego batalion przeznaczony dla KOP. 26 października mjr Jan Prokop ${ }^{14}$, dowódca jednostki, rozkazem nr 11/24 powierzył mu dowództwo plutonu w 2 kompanii. Z początkiem listopada $1924 \mathrm{r}$. batalion objął ochronę 57-kilometrowego odcinka granicy polsko-radzieckiej pomiędzy słupami granicznymi nr 927 (Kuncowszczyzna) do nr 964 (Kołki) na terenie powiatu Nieśwież. Był to czas wzmożonej służby na granicy związanej ze stałym zagrożeniem ze strony radzieckich grup dywersyjnych oraz pospo-

Śledziński Kazimierz, Karta ewidencyjna, kadra baonu zapasowego 10 pp, Łowicz 3 IX 1923 r. [1927 r.], b.p.

${ }^{13}$ Ibidem.

${ }^{14}$ Jan Prokop (ur. 1891- zm. 1958) - ppłk. Wywodził się z armii rosyjskiej, w której służył od 1908 r. Od 24 XI 1914 r. w niewoli niemieckiej. 12 XI 1916 r. zgłosił akces do służby w Legionach Polskich. Pozostawiony w Offizier Polenlager, działał w POW. Zwolniony na początku 1919 r. W czasie wojny polsko-rosyjskiej (1918-1921) por. w Kowieńskim pp (później 77 pp) i w grupie płk. Stefana Pasławskiego (20 VII - 1 VIII 1919 r.), dowódca kompanii i wz. dowódca batalionu. Następnie służył na polsko-litewskim froncie Litwy Środkowej. Od 25 I 1922 r. oficer 80 pp w Słonimiu, później dowódca II/75 pp w Królewskiej Hucie. 3 X 1924 r. przeniesiony do 9 Batalionu KOP w Klecku. 19 XI 1925 r. zdjęty ze stanowiska, pozostawał w dyspozycji dowódcy 2 Brygady KOP. Od 22 III 1926 r. dowódca III/78 pp w Baranowiczach, w 1928 r. dowódca III/54 pp, następnie oficer placu w Tarnopolu, komendant placu w Toruniu i komendant Powiatowej Komisji Uzupełnień w Kościerzynie. Od 31 VII 1934 r. w stanie spoczynku. 20 IX 1939 r. aresztowany przez Rosjan, przebywał w obozach Ludowego Komisariatu Spraw Wewnętrznych w Juchnowie i Griazowcu. Od 3 IX 1941 r. w obozie Tockoje, w Armii Polskiej w ZSRR gen. Władysława Andersa. Następnie służył w Polskich Siłach Zbrojnych na Zachodzie. Odznaczony m.in.: orderem Virtuti Militari (VM) 5 kl., Krzyżem Walecznych (KW) czterokrotnie, Krzyżem Zasługi Wojsk Litwy Środkowej. Zob. CAW-WBH, AP 4319, Prokop Jan, Wniosek do Komitetu Krzyża i Medalu Niepodległości, [Warszawa 1937 r.], b.p.; Zaświadczenie WBH, Warszawa 21 XII 1937 r., b.p.; Arkusz ewidencyjno-kwalifikacyjny, Baranowicze 1928 r., b.p.; Rocznik oficerski 1928, Warszawa 1928, s. 68, 167; Indeks represjonowanych IPN, https://indeksrepresjonowanych.pl/ (dostęp 10 II 2020 r.). 
litych band rabunkowych grasujących na pograniczu. 2 kompania graniczna „Chominka”, w której pełnił służbę ppor. Śledziński, miała do ochrony 28,6 km odcinek granicy polsko-radzieckiej (od słupa nr 927 do nr 964) położony na terenie gminy Zaostrowiecze (pow. nieświeski). Bezpośrednio na linii granicy służbę pełnili żołnierze ze strażnic: „Kuncowszczyzna” (nr 133), „Helenowo” (nr 134), „Morocz” (nr 135) i „Kołki” (nr 136), nad którymi ppor. Śledziński sprawował nadzór jako oficer młodszy kompanii. Dowództwo kompanii granicznej rozmieszczone zostało w budynkach należących do leśnictwa Chominka, położonego na południe od Zaostrowiecza. Leśnictwo znajdowało się z dala od większych miejscowości, tj. 14 km drogą polną do Hrycewicz, gdzie była poczta i telegraf. Najbliższa stacja kolejowa Reytanów - znajdująca się na linii kolejowej Baranowicze-Łuniniec, odległa była o $46 \mathrm{~km}(34 \mathrm{~km} \text { szosą i } 12 \mathrm{~km} \text { polną drogą })^{15}$.

Lata 1924-1926 były okresem ciężkiej służby na pograniczu, trudnej zwłaszcza na Nowogródczyźnie pozbawionej większych miejscowości i utwardzonych dróg, gdzie małe wioski i zaścianki były słabo dostępne, a granica położona na bagnistym terenie była bardzo trudna do ochrony. Szczególnie uciążliwa była zima 1924/1925, gdy żołnierze dopiero zapoznawali się z terenem, ludnością oraz specyfiką służby w warunkach zimowych i w czasie wiosennych roztopów, gdy nie wszędzie dało się dotrzeć suchą nogą. Zadaniem ppor. Śledzińskiego jako młodszego oficera kompanii było przede wszystkim kontrolowanie pełnienia służby w strażnicach i na wyznaczonych im odcinkach granicy, oraz nadzorowanie, aby w strażnicach utrzymany był należyty ład i porządek, a żołnierze byli właściwie odżywieni i wyposażeni. Ponadto pod nieobecność dowódcy kompanii zastępował go w jego obowiązkach.

Po rocznym okresie służby w KOP, 17 listopada 1925 r. ppor. Śledziński otrzymał pochwałę $\mathrm{w}$ rozkazie tajnym dowódcy batalionu nr 45/1925: „za wytężoną pracę dla dobra ojczyzny”. Z tego okresu pochodzi jego opinia służbowa za 1925 r., w której jego przełożony kpt. Wilhelm Paszkiewicz napisał m.in.: „nie jest zrównoważony i stały, jednak niezwykle chętny, pełny werwy i entuzjazmu, zamiłowany do służby wojsk.[owej] i patriota. Ambitny o wysokim poczuciu honoru, lubiany przez kolegów oraz podwładnych. Pod względem fizycznym jest bez zarzutu, zdrów, wytrzymały i ruchliwy. Młody, ale się wyrobi gdyż pracuje nad sobą i dobrych rad chętnie słucha. [...] W służbie i poza służbą zachowuje się wzorowo. [...] Ma wszelkie dane ku temu, że wyrobi się na bardzo dobrego d-cę [dowódcę] komp. Na razie za młody". Powyższą ocenę ppor. Śledzińskiego podzielili wyżsi przełożeni, a mjr Zygmunt Piwnicki, dowódca batalionu, dodatkowo wspomniał:

${ }^{15}$ ASGr, Dowództwo KOP, sygn. 177/144, Komunikat dyslokacyjny KOP, Ministerstwo Spraw Wewnętrznych 1.dz.7600/tjn. Op.Wyszk., Warszawa 1928 r., k. 3, 7; Komunikat dyslokacyjny KOP, Ministerstwo Spraw Wewnętrznych ldz.KOP.599/Tj./Og./Org./32, Warszawa czerwiec 1932 r., k. 20-21. 
„o żołnierza dbały”'6. Wkrótce też, 23 grudnia 1925 r., zgodnie z Dziennikiem Personalnym MSWojsk. 1925, nr 136, otrzymał awans na porucznika ${ }^{17}$.

Porucznik Śledziński był oficerem cenionym zarówno przez podległych mu żołnierzy, jak i przełożonych, którzy doceniali m.in. jego ofiarność w pełnieniu służby na pograniczu. W Chomince zastała go kolejna, druga z rzędu kresowa zima. $\mathrm{Z}$ zachowanych rozkazów batalionu wynika, że jako młodszemu oficerowi kompanii, przypadała mu zazwyczaj druga tura urlopu świątecznego, tj. na przełomie stycznia i lutego. W 1926 r. swój urlop zamierzał spędzić w Warszawie. Wieczorem 1 lutego por. Śledziński był jednym z pasażerów autobusu rejsowego jadącego z Sieniawki do stacji kolejowej Lachowicze. Tego dnia przepełnionym autobusem kierował Antoni Kobiak, który w nocnych ciemnościach rozświetlonych jedynie przez reflektory pojazdu, w ostatniej chwili zauważył na drodze sanie tarasujące przejazd. Autobus zatrzymał się gwałtownie, a silne szarpnięcie przebudziło śpiących pasażerów. W momencie zatrzymania kierowca chwycił się za pierś, a po chwili bezwładnie osunął się na siedzenie trafiony kulą, która przebiła przednią szybę. Rozległy się kolejne strzały oraz jęk jednego z postrzelonych pasażerów. Wśród podróżnych zapanowały popłoch i przerażenie, które zdołał opanować por. Śledziński, głośno nakazując wszystkim wyjście $z$ autobusu i położenie się na ziemi. Oficer, widząc w świetle reflektorów kilka sylwetek napastników, założył że ci będą starali się obrabować podróżnych. W tym czasie bandyci ponownie ostrzelali autobus, a kilka kul przebiło karoserię. Porucznik Śledziński, jako jedyny uzbrojony (w pistolet Browning), sporadycznie odpowiadał strzałami spoza samochodu, raniąc napastników uzbrojonych w karabiny. Ich wściekłość narastała, zwłaszcza gdy jeden z nich, który zbyt mocno się wychylił, padł martwy, ugodzony celnym strzałem oddanym przez oficera. Bandyci strzelali w jego stronę, a jedna z kul rozdarła jego płaszcz i otarła się o pierś. Nagły błysk i huk rozrywającego się granatu poderwał ukrywających się pasażerów. Rozległy się jęki ranionych odłamkami. Jednym z rannych był

${ }^{16}$ Należy wspomnieć, że w latach 1926-1927 Wojskowy Sąd Okręgowy (WSO) nr IX w Brześciu n. Bugiem rozpatrywał sprawę karną w stosunku do ppor. Śledzińskiego jako oskarżonego o nadużycie władzy wobec jednego z żołnierzy, tj. pisarza kompanii. Czyn miał zostać popełniony w 1925 r. Śledztwo sądowe wdrożono 23 XI 1925 r., ale dopiero 7 VI 1926 r. wniesiono akt oskarżenia. 19 IV 1927 r. został uwolniony od oskarżenia sądowego, a sprawa skierowana do postępowania honorowego. Ostatecznie wyrokiem Ko 891/25 z 17 XI 927 r. został uwolniony od zarzutu z powodu braku dowodów. Zob. CAW-WBH, AP 12491, Śledziński Kazimierz, Roczne uzupełnienie listy kwalifikacyjnej za rok 1925, Kleck 1 XI 1925 r., b.p.; Przesłanie odpisu prawomocnego wyroku WSO nr IX z 17 XI 1927 r., Brześć nad Bugiem 12 IV 1927 r., b.p.; Karta ewidencyjna, odpis, Łowicz 3 IX 1923 r. [1927 r.], b.p.

${ }^{17}$ Starszeństwo z dn. 1 VII 1925 r., lok. 51, Dz. Pers. MSWojsk. 1925, nr 136. Zob. CAW-WBH, AP 12491, Śledziński Kazimierz, Karta ewidencyjna, kadra baonu zapasowego 10 pp, Łowicz 3 IX 1923 r. [1927 r.], b.p.; ASGr, Dowództwo KOP, sygn. 177/11, Rozkaz KOP nr 143, Warszawa 31 XII 1925 r., k. 493. 
także por. Śledziński, który otrzymał z bliska postrzał w twarz. Napastnicy wykorzystali moment wybuchu, aby porzucić sanie oraz zwłoki towarzysza i uciec z miejsca napadu, ale na śniegu pozostawiło krwawy trop dwóch ranionych bandytów. Oficer pomimo ciężkiej rany i upływu krwi, pieszo, przy siarczystym mrozie, ruszył w kierunku Sieniawki aby wezwać pomoc dla rannych. Na szczęście po około 5,5 km marszu napotkał samochód z patrolem policji, który jechał w kierunku odgłosów strzelaniny. Nadjechał także patrol ułanów z 10 Szwadronu KOP stacjonującego w Radziwiłmontach oraz nadciągnęli żołnierze z odwodu batalionowego. Porucznik Śledziński miał na tyle sił, aby opowiedzieć o napadzie i naprowadzić pościg na ślad uciekających napastników. W tym czasie ranni pasażerowie zostali zabrani przez drugi autobus jadący do Nieświeża. Również ciało zabitego kierowcy trafiło do miasteczka, gdzie o całym zajściu powiadomiony został miejscowy posterunek policji. Żołnierze KOP prowadzeni przez Lorda - psa tropiącego chor. Wacława Markowskiego ${ }^{18}$ - po śnieżnym śladzie dotarli do wiosek Hajnin i Kulenie, które po otoczeniu zostały przeszukane. Po szesnastu godzinach od napadu wszyscy członkowie bandy zostali zatrzymani, z wyjątkiem herszta Antona Szpaka, który został zabity w trakcie napadu przez por. Śledzińskiego. Szajka grasowała w rejonie Lachowicz od 1924 r. i początkowo wspierana była zza granicy radzieckiej. Bez wątpienia była inspirowana przez tamtejszy wywiad. Dokonała przypuszczalnie dziesięciu napadów, m.in. na stację kolejową w Lachowiczach, na pobliskie dwory oraz na okolicznych drogach ${ }^{19}$.

Tylko dzięki poświęceniu por. Śledzińskiego natychmiast podjęty pościg doprowadził do ujęcia groźnych napastników, dając tym samym dowód na prawdziwość słów gen. Minkiewicza: „Żołnierze, spełnijcie - mimo

${ }^{18}$ Wacław Markowski (ur. 1896 - zm. ?) - chor. Był komendantem utworzonej w 1925 r. Doświadczalnej Stacji Psów Meldunkowo-Śledczych KOP w Klecku. Stacja podlegała szefowi łączności KOP, pod względem służbowym dowódcy 2 Brygady KOP, a gospodarczo dowództwu 9 Batalionu KOP w Klecku. Stacja zmieniała dwukrotnie nazwy na: Stacja Hodowlano-Ćwiczebna Psów Meldunkowych; 1926/1927 na Szkoła Tresury Psów Meldunkowych. Została zlikwidowana 31 I 1934 r. w związku z utworzeniem wojskowej stacji psów służbowych w Rembertowie. Zob. P. Skubisz, Psy meldunkowo-śledcze w służbie Korpusu Ochrony Pogranicza w latach 1924-1939, „Biuletyn Centralnego Ośrodka Szkolenia Straży Granicznej w Koszalinie” 2006, nr 1, s. 202-205.

${ }^{19}$ Według jednej z wersji został raniony w twarz odłamkiem wybuchającego granatu. Z niewiadomych przyczyn relacja ze zdarzenia została zamieszczona w dwutygodniku "Szofer Polski” dopiero w kwietniu 1927 r. z informacją, że miało miejsce „w ubiegłym tygodniu”. Zob. Do ostatniego naboju [w:] Korpus Ochrony Pogranicza w druga rocznicę objęcia stużby na granicach Rzeczypospolitej 1925-1926, [Warszawa 1926], s. 53-54; Ci którzy odeszli... Ś.p. por Kazimierz Śledziński, „Polska Zbrojna”, 13 XII 1927, s. 4 [także w: Korpus Ochrony Pogranicza $w$ trzecia rocznicę..., s. 58]; Napad bandytów na autobus. Na posterunku swym zginą szofer autobusowy, „Szofer Polski. Dwutygodnik ilustrowany ogólno-autobusowy” 1927, nr 7, [1 IV 1927 r.], s. 12, https://www.wbc.poznan.pl/dlibra/publication/401340/ edition/316245/content (dostęp 8 XII 2019 r.). 
trudnych warunków służby - swój żołnierski obowiązek, a zaskarbicie sobie dobrą pamięć Ojczyzny” ${ }^{20}$. Pierwszą pochwałę: „za brawurę, męstwo i waleczne zachowanie się podczas napadu" por. Śledziński otrzymał w tajnym rozkazie dowódcy 9 Batalionu KOP, 3 maja 1926 r., podczas batalionowej uroczystości z okazji Święta Konstytucji 3 Maja zorganizowanej w Klecku; mjr Zygmunt Piwnicki ${ }^{21}$ odznaczył por. Śledzińskiego Srebrnym Krzyżem Zasługi. Odznaczanie to nadane zostało specjalnym rozporządzeniem Prezesa Rady Ministrów z 6 marca 1926 r. ${ }^{22}$ Ponadto „za waleczność” gen. broni Lucjan Żeligowski, ówczesny minister spraw wojskowych, wyróżnił dzielnego oficera pamiątkową, złotą szablą z grawerowaną dedykacją ${ }^{23}$.

${ }^{20}$ Dokument $n r$ 23..., s. 47.

${ }^{21}$ Zygmunt Maria Piwnicki ps. „Orlicz” (ur. 1895 w Krzeszowicach - zm. 1943 w Warszawie) - płk, żołnierz Legionów Polskich i II Korpusu Polskiego gen. Józefa Hallera. W 1920 r. jako kpt. był dowódcą I/101 pp (późniejszy 84 pp) podczas wojny polsko-rosyjskiej (1918-1921). Od 21 X 1922 r. dowódca III/36 pp Legii Akademickiej w Warszawie (12 V 1925 r. otrzymał pochwały w rozkazie od dowódców 28 DP i 36 pp). Z dniem 25 II 1925 r. przydzielony do KOP na stanowisko dowódcy 13 Batalionu KOP w Kopyczyńcach. 7 IV 1925 r. objął stanowisko I oficera sztabu dowództwa 4 Brygady KOP (Podole). 6 IX 1925 r. oddelegowany do Dowództwa KOP. 28 X 1928 r. otrzymał pochwałę w rozkazie dowódcy 4 Brygady KOP. Rozkazem z 22 X 1925 r. mianowany dowódcą 9 Batalionu KOP (w miejsce mjr. Jana Prokopa). 10 IV 1928 r. dopuszczony do egzaminu do Wyższej Szkoły Wojennej w Warszawie. Rozporządzeniem z 29 maja 1928 r. przeniesiony z KOP na stanowisko dowódcy II/3 Pułku Strzelców Podhalańskich w Bielsku. 19 VI 1928 r. zdał dowództwo Batalionu KOP w Klecku. 17 XII 1928 r. nadano mu odznakę KOP „Za służbę graniczną”. Służył kolejno jako dowódca batalionu, komendant Przysposobienia Wojskowego przy 21 DP Górskiej, kierownik Okręgu Wychowania Fizycznego i Przysposobienia Wojskowego (WFiPW) nr VIII w Toruniu, zastępca dowódcy 25 pp w Piotrkowie, kierownik Okręgu WFiPW nr I, a zarazem dowódca Warszawskiej Brygady Obrony Narodowej. We wrześniu 1939 r. dowódca 202 pp. Zob. ASGr, Dowództwo KOP, sygn. 177/11, Rozkaz dzienny KOP nr 113, Warszawa 23 X 1925 r., k. 411; sygn. 177/14, Rozkaz nr 18, Warszawa 29 II 1928 r., k. 55-56; Rozkaz nr 26, Warszawa 15 III 1928 r., k. 82; Rozkaz nr 63, Warszawa 6 VI 1928 r., k. 184-187; Rozkaz nr 121, Warszawa 17 XII 1928 r., k. 404; Brygada KOP „Podole”, sygn. 185/2, Rozkaz nr 8, Czortków 7 IV 1925 r., k. 12; Rozkaz nr 18, Czortków 12 V 1925 r., k. 37; Rozkaz nr 34, Czortków 4 VIII 1925 r., k. 95; Rozkaz nr 40, Czortków 7 IX 1925 r., k. 117; Rozkaz nr 52, Czortków 28 X 1925 r., k. 157; Brygada KOP „Nowogródek”, sygn. 182/2, Rozkaz dzienny nr 48, Baranowicze 25 XI 1926 r., k. 93; sygn.182/3, Rozkaz dzienny nr 67, Baranowicze 5 XII 1927 r., k. 141; sygn. 182/4, Rozkaz dzienny nr 1, Baranowicze 3 I 1928 r., k. 1; Rozkaz dzienny nr 18, Baranowicze 6 IV 1928 r., k. 51; Rozkaz dzienny nr 29, Baranowicze 20 VI 1928 r., k. 83; Dz. Pers. MSWojsk. 1925, nr $75 \mathrm{Z}$

${ }^{22}$ Rozporządzenie dotyczyło tylko por. Śledzińskiego. Zostało podane w Dz. Pers. MSWojsk. 1926, nr 20 [z 8 V 1926 r.], s. 154, https://www.wbc.poznan.pl/dlibra/publication/79850/ edition/93999/content (dostęp 29 XII 2019 r.); CAW-WBH, AP 12491, Śledziński Kazimierz, Główna karta ewidencyjna, odpis, Łowicz 3 IX 1923 r. [1927 r.], b.p.

${ }^{23}$ ASGr, Dowództwo KOP, sygn. 177/65, Rozkaz wewnętrzny nr 111 z 12 XII 1927 r., Warszawa, k. 136; Do ostatniego naboju..., s. 53-54; Lista imienna oficerów i szeregowych KOP odznaczonych „Krzyżem Zasługi” [w:] Korpus Ochrony Pogranicza w druga rocznicę..., s. 66-67. 
Porucznik Śledziński w dzień po wydarzeniach pod Sieniawką został przewieziony do Szpitala Okręgowego nr I w Warszawie, celem leczenia rany postrzałowej twarzy. 15 marca ze względu na stan zdrowia płk dr med. Stefan Hubicki, komendant szpitala Oficerskiej Szkoły Sanitarnej, udzielił mu czterotygodniowego urlopu zdrowotnego. Dopiero 13 kwietnia, po zaleczeniu rany, powrócił do normalnej służby w batalionie, gdzie otrzymał przydział do kompanii odwodowej w Klecku ${ }^{24}$. Przez krótki czas, tj. w okresie od 8 lipca do 6 sierpnia 1926 r., był w zastępstwie oficerem ordynansowym płk. Bronisława Ostrowskiego ${ }^{25}$, dowódcy nowogródzkiej 2 Brygady KOP w Baranowiczach ${ }^{26}$. Niestety, podczas dramatycznych wydarzeń pod Sieniawką, na skutek odniesionych obrażeń i długiego oczekiwania na pomoc lekarską przy siarczystym mrozie, a także wskutek wstrząsu psychicznego, które skutkowały osłabieniem organizmu, por. Śledziński nabawił się gruźlicy płuc i krtani. Z początkiem sierpnia lekarz batalionu por. lek. Tadeusz Rakowiecki postawił wniosek o skierowanie oficera przed lekarską komisję rewizyjną jako całkowicie niezdolnego do służby wojskowej. W opinii do tego wniosku mjr Piwnicki, dowódca batalionu, napisał o por. Śledzińskim: „oficer o wybitnym poczuciu honoru i godności własnej. Charakter wybitnie prawy i rycerski, szczery, ambitny, pogodny i wesoły, całym sercem oddany służbie"27. Jako przełożony uznał też, że choroba to wynik złych warunków

\footnotetext{
${ }^{24}$ Według karty ewidencyjnej do 4 kompanii, ale batalion miał trzy kompanie graniczne i odwodową jako czwartą. Zob. CAW-WBH, AP 12491, Śledziński Kazimierz, Główna karta ewidencyjna, odpis, Łowicz 3 IX 1923 r. [1927 r.], b.p.
}

${ }^{25}$ Bronisław Ostrowski (ur. 1880 w Chrepitowie - zm. 1966) - płk, wywodził się z armii rosyjskiej (od 1900 r.). W czasie I wojny światowej oficer w 205 i 645 pp na froncie wschodnim. Od 4 III 1917 r. służył w 1 Dywizji Strzelców Polskich w ramach I Korpusu Polskiego. 11 XII 1919 r. w WP jako ppłk dowódca batalionu, a następnie w 23 pp. W czasie wojny polsko-rosyjskiej (1918-1921) dowódca pułku i wz. dowódca 3 DPLeg. Ranny w czasie walk. Odznaczony VM i KW. Od 26 VIII 1920 r. dowódca 9 ppLeg. 24 VI 1926 r. przeniesiony do KOP na dowódcę poleskiej 5 Brygady KOP. 26 VII 1926 r. wyznaczony na dowódcę nowogródzkiej 2 Brygady KOP. 1 III 1928 r. przeniesiony z KOP do dyspozycji Ministra Skarbu. Do 7 XI 1928 r. zastępca komendanta Straży Granicznej w Warszawie. Następnie przydzielony do komisji przyjęć oficerów rezerwy MSWojsk. Z 31 XII 1930 r. przeniesiony w stan spoczynku. Otrzymał przydział ziemi pod Komarowem. We wrześniu 1939 r. cudem uniknął rozstrzelania przez żołnierzy Armii Czerwonej. W czasie okupacji mieszkał w Lublinie i Zamościu. Zob. CAW-WBH, AP 593, Ostrowski Bronisław; ASGr, Komenda Straży Granicznej (1928-1939), sygn. 187/30, Rozkaz nr 19, Warszawa 19 IV 1928 r., k. 8; Rozkaz nr 62, Warszawa 15 X 1928 r., k. 267; Rozkaz nr 66, Warszawa 1 XII 1928 r., k. 287; A. Kędziora, Zamościopedia, zamosciopedia.pl (dostęp 20 II 2020 r.).

${ }^{26}$ Zastępował podczas urlopu por. Henryka Miedzińskiego. 13 VIII 1926 r. powrócił do batalionu. Zob. ASGr, Brygada KOP „Nowogródek”, sygn. 182/2, Rozkaz nr 16/26, Baranowicze 15 VIII 1926 r., k. 38; Rozkaz nr 21/26, Baranowicze 13 VIII 1926 r., k. 48.

${ }^{27}$ Lekarz na podstawie wywiadu lekarskiego (matka zmarła na gruźlicę) oceniał, że bardzo złe warunki służby na granicy mogły odnowić chorobę lub ją uaktywnić. Skłaniał się 
służby i wydarzeń pod Sieniawką. Ze względu na całkowitą utratę zdolności do pracy dowództwo batalionu podjęło starania o ratowanie zdrowia por. Śledzińskiego ${ }^{28} .10$ sierpnia wysłano go na sześciotygodniowy urlop zdrowotny. 28 października ponownie skierowano go na kurację, tym razem do Szpitala Okręgowego nr IX w Brześciu nad Bugiem. Po powrocie do batalionu, 9 listopada, na podstawie orzeczenia lekarskiego udzielono mu sześciomiesięcznego urlopu kuracyjnego. W trakcie urlopu, 31 marca $1927 \mathrm{r}$. trafił na leczenie do szpitala wojskowego w Rajczy (Dowództwo Okręgu Korpusu nr V). Formalnie ze względu na pobyt na długotrwałym zwolnieniu lekarskim, od 10 maja był w ewidencji kadry oficerów Departamentu Piechoty. Jego stan zdrowia uległ poprawie na tyle, że 12 września 1927 r. powrócił do służby w batalionie, tym razem w 1 kompanii granicznej „Lubieniec”. Kilka dni później, 25 września przesunięto go do kadry kompanii szkolnej na stanowisko oficera młodszego i instruktora. Niestety, 31 października ponownie trafił do Szpitala Okręgowego nr I w Warszawie. Przebywał na oddziale przy ul. Zakroczymskiej 6, pod opieką por. dr. med. Stanisława Englerta ${ }^{29}$. Pomimo opieki medycznej i starań lekarzy, po długiej i ciężkiej chorobie, zmarł 11 grudnia 1927 r. ${ }^{30}$ Porucznik Śledziński nie miał bliskiej rodziny w Warszawie, nie zdążył założyć własnej i zmarł bezpotomnie w dwudziestym piątym roku życia.

Dowódca KOP gen. dyw. Minkiewicz organizację pogrzebu por. Śledzińskiego powierzył ppłk. lek. Stanisławowi Michałowskiemu, szefowi służby sanitarnej $\mathrm{KOP}^{31}$, oraz por. Gustawowi Olszewskiemu ${ }^{32}$. Do udziału

jednak do wniosku, że ze względu na to, że przed napadem por. Śledziński nie chorował, to wydarzenia z 2 II 1926 r. spowodowały jej rozwój. Zob. CAW-WBH, AP 12491, Śledziński Kazimierz, Lista rewizyjna, Kleck 19 VIII 1927 r., b.p.

${ }^{28}$ Świadczy o tym treść korespondencji kierowanej przez dowódcę batalionu do szefostw sanitarnych różnych Dowództw Okręgów Korpusów, w których leczony był por. Śledziński.

${ }^{29}$ Stanisław Englert (ur. 1891 - zm. 1940) - mjr, lekarz oddziału zakaźnego Szpitala Okręgowego nr I. Zob. Lista starszeństwa oficerów zawodowych korpus sanitarnego, Warszawa 1934, s. 32.

${ }^{30}$ CAW-WBH, AP 12491, Śledziński Kazimierz, Główna karta ewidencyjna, odpis, Łowicz 3 IX 1923 r. [1927 r.], b.p.; Roczne uzupełnienie listy kwalifikacyjnej za rok 1927, Kleck 5 XI 1927 r., b.p.; Orzeczenie lekarskie, Rajcza 6 VIII 1927 r., b.p.; Wyciąg z księgi chorych 9 Batalionu KOP w Klecku, Kleck 1927 r., b.p.; Metryka śmierci rzymsko-katolickiej Parafii Wojskowej pw. NMP Królowej Polski w Warszawie, Warszawa 28 I 1928 r., b.p.

${ }^{31}$ Pułkownik Stanisław Michałowski był szefem służby sanitarnej KOP w okresie od 1924 do 28 II 1930 r. Zob. A. Ochał, Stużba zdrowia Korpusu Ochrony Pogranicza (1924-1939). Lekarze i sanitariusze w stużbie żołnierzy i ludności kresowej II Rzeczypospolitej [w:] Medycy polskiego pogranicza II Rzeczypospolitej 1918-1939, red. B. Urbanek, Warszawa 2018, s. 355-394.

${ }^{32}$ Gustaw Stanisław Olszewski (ur. 1899 - zm. ?) - por., przydzielony do KOP z 44 pp w Równem. Początkowo pełnił służbę w 7 Batalionie KOP w Podświlu. 10 VI 1925 r. przeniesiony 
w eksportacji i w pogrzebie na Cmentarzu Powązkowskim zostali wyznaczeni niemal wszyscy oficerowie i szeregowi Dowództwa KOP w Warszawie. Nabożeństwo żałobne odbyło się 14 grudnia 1927 r. o godz. 9.30 w kościele garnizonowym Parafii Wojskowej pw. NMP Królowej Polski przy ul. Długiej. Prawdopodobnie poprowadził je ks. prałat Jan Podbielski, starszy kapelan wojskowy m.in. filii Szpitala Okręgowego nr I w Warszawie ${ }^{33}$.

W marcu 1928 r. ustanowiony został Krzyż Zasługi za Dzielność, który nadawany był żołnierzom Korpusu Ochrony Pogranicza i funkcjonariuszom Straży Celnej za wykazaną dzielność i czyny dokonane w specjalnie ciężkich warunkach, z wykazaniem się wyjątkową odwagą, z narażeniem zdrowia lub życia, w obronie prawa, nietykalności granic państwowych oraz życia i mienia obywateli ${ }^{34}$. W kwietniu 1928 r. Krzyż został nadany pierwszym żołnierzom KOP, a jednym z nich był właśnie por. Śledziński, któremu nadano go pośmiertnie w zamian za Srebrny Krzyż Zasługi ${ }^{35}$.

do dowództwa 5 Brygady KOP. Rozkazem z 27 I 1926 r. przeniesiony do dowództwa KOP w Warszawie. 8 XI 1928 r. przyznano mu prawo do Medalu za Wojnę 1918-1921. 8 XI 1928 r. Prezes Rady Ministrów nadał mu Srebrny Krzyż Zasługi za dokonania przy organizacji KOP. 13 XII 1928 r. prawo do Medalu Dziesięciolecia Odzyskanej Niepodległości. 17 XII 1928 r. wyróżniony Odznaką KOP „Za służbę graniczną”. Od 24 II do 19 III 1928 r. uczestniczył w kursie narciarskim w Krynicy. Uczestniczył w komisjach przetargowych m.in. na sprzęt narciarski dla KOP. 8 V 1931 r. przeniesiony z KOP do 30 pp w Warszawie. Zob. Dz. Pers. MSWojsk. 1931, nr 3; ASGr, Dowództwo KOP, sygn. 177/11, Rozkaz nr 54, Warszawa 6 V 1925 r., k. 193; sygn. 177/12, Rozkaz nr 9, Warszawa 27 I 1927 r., k. 33; sygn. 177/14, Rozkaz nr 108, Warszawa 8 XI 1928 r., k. 344; Rozkaz nr 110, Warszawa 12 XI 1928 r., k. 354-355; Rozkaz nr 119, Warszawa 13 XII 1928 r., k. 389-390; Rozkaz nr 121, Warszawa 17 XII 1928 r., k. 396-397; Rozkaz wewnętrzny nr 14, Warszawa 27 II 1928 r., k. 461-462; Rozkaz wewnętrzny KOP nr 68, Warszawa 3 VIII 1928 r., k. 526; Rocznik oficerski 1928..., s. $150,258$.

${ }^{33}$ CAW-WBH, AP 12491, Śledziński Kazimierz, Metryka śmierci rzymsko-katolickiej Parafii Wojskowej pw. NMP Królowej Polski, Warszawa 28 I 1928 r., b.p.; Klepsydra żałobna, „Polska Zbrojna”, 13 XII 1927, s. 5; Wykaz duchowieństwa wojskowego oraz parafi, kościołów i kaplic wojskowych wyznania katolickiego w Rzeczypospolitej Polskiej na 1930 r., Warszawa 1930, s. $12,35$.

${ }^{34}$ Krzyż nadawany był żołnierzom KOP, funkcjonariuszom Policji Państwowej i Straży Celnej (1921-1928), a od jesieni 1928 r. także strażnikom Straży Granicznej (1928-1939), od maja 1939 r. też żołnierzom WP. Nadawał go prezes Rady Ministrów na wniosek właściwego ministra, tj. spraw wewnętrznych, skarbu lub spraw wojskowych. $Z$ nadaniem wiązała się dożywotnia pensja, tj. 200 zł rocznie (płatna 2 stycznia). Zob. Rozporządzenie Prezydenta RP z 7 III 1928 r. o ustanowieniu Krzyża za Dzielność (Dz.U. z 1928 r., nr 30, poz. 279).

${ }^{35}$ Dowódca KOP wnioskował, aby odznaczenie por. Śledzińskiego nosiło numer 1. Wniosek zaakceptował minister Felicjan Sławoj-Składkowski. Wśród odznaczonych Krzyżem Zasługi za Dzielność był także por. Zygmunt Elsner i 12 innych żołnierzy KOP. Wszyscy otrzymali go w zamian za wcześniej nadane im Krzyże Zasługi. Zarządzenie prezydenta RP podano w Monitorze Polskim 1928, nr 89, poz. 145. Zob. ASGr, Dowództwo KOP, sygn. 177/14, Rozkaz nr 49 z 2 V 1928 r., Warszawa, k. 152; CAW-WBH, AP 26139, Kazimierz Śledziński, Wniosek o odznaczenie Krzyżem Zasługi za Dzielność, [Felicjan] Sławoj-Składkowski, 
Według historyków (m.in. Piotra Cichorackiego) okres masowej radzieckiej dywersji na Kresach Wschodnich II Rzeczypospolitej zakończył się wiosną 1925 r., gdy ostatnie większe oddziały działające po polskiej stronie granicy przeszły na terytorium radzieckie. Ich wyjście traktowane jest jako zamknięcie okresu „walk partyzanckich” na wschodnim pograniczu, choć nie oznaczało to końca zwalczania dywersji przez KOP. Wprawdzie część dywersantów przeszła na radziecką stronę, ale pozostali mieli „wtopić” się w miejscowe społeczeństwo i pozostać w ukryciu ${ }^{36}$. Pozostałości grup (band) były sukcesywnie rozpoznawane i likwidowane przez organy bezpieczeństwa (policja, KOP) w kolejnych miesiącach, choć nie we wszystkich przypadkach było to możliwe. Prawdopodobnie napadu pod Sieniawką, o typowo kryminalnym charakterze, dokonała grupa byłych dywersantów, którzy zdemoralizowani wcześniejszymi działaniami szukali możliwości łatwego rabunku. Nieoczekiwanie dla napastników skuteczny opór stawił im jeden z podróżnych - oficer KOP.

Po raz ostatni nazwisko por. Śledzińskiego przypomniane zostało w rozkazach KOP w sierpniu 1929 r., gdy gen. bryg. Stanisław Zosik-Tessaro, dowódca formacji, zwrócił się z apelem do oficerów o pomoc finansową na ufundowanie nagrobka na zaniedbanej mogile poległego oficera. Składka miała być wyrazem hołdu i uznania dla dzielności por. Śledzińskiego, ale niestety nie wszędzie apel dowódcy spotkał się z należytym zrozumieniem oficerów formacji, którzy nie wzięli udziału w zbiórce pieniędzy ${ }^{37}$. Po wielu latach zapomnienia, gdy nagrobek por. Śledzińskiego na wojskowych Powązkach został zatarty przez czas, może warto choć niniejszym artykułem przypomnieć jego mężny czyn i odwagę okazaną w obronie współobywateli i II Rzeczypospolitej Polskiej. Tym samym postawić go jako przykład żołnierskiej ofiarności, któremu bliskie były słowa dowódcy KOP: „Musicie stać się naprawdę obrońcami biednej, żyjącej w ciągłej obawie o swoje życie i mienie ludności. Musicie wierną wytrwałą służbą zapewnić ludności ład i pokój, zagwarantować bezpieczeństwo. Imię Wasze, imię żołnierza Korpusu powołanego do ochrony granic musi być $\mathrm{z}$ ufnością wymawiane przez całą ludność, a jednocześnie musi być postrachem dla zbrojnych bandytów"38. Brawurowe i odważne działanie por. Śledzińskiego doprowadziło do rozbicia

Warszawa 3 IV 1928 r., k. 1; Lista odznaczonych, Korpus Ochrony Pogranicza w czwarta rocznice objęcia stużby na granicach Rzeczypospolitej 1927-1928, Warszawa [1928 r.], s. 80-81.

${ }^{36}$ P. Cichoracki, Stołpce-Łowcza-Leśna 1924. II Rzeczypospolita wobec najpoważniejszych incydentów zbrojnych $w$ województwach pótnocno-wschodnich, Łomianki 2012, s. 273 (przyp. 15), 277-279.

${ }^{37}$ ASGr, Dowództwo KOP, sygn. 177/37, Rozkaz tajny nr 14 z 23 VIII 1929 r., Warszawa, k. 22.

${ }^{38}$ Dokument $n$ r 23..., s. 47. 
niebezpiecznej bandy działającej na pograniczu, ale za cenę jego zdrowia, a w konsekwencji także i młodego życia.

\section{Bibliografia}

\section{Archiwalia}

Archiwum Straży Granicznej w Szczecinie zesp. 177: Dowództwo KOP zesp. 182: Brygada KOP „Nowogródek” zesp. 185: Brygada KOP „Podole” zesp. 187: Komenda Straży Granicznej (1928-1939)

Centralne Archiwum Wojskowe Wojskowego Biura Historycznego Kolekcja akt personalnych i odznaczeniowych

\section{Dokumenty drukowane}

Lista starszeństwa oficerów zawodowych korpus sanitarnego, Warszawa 1934.

O Niepodległa i granice, t. 4: Korpus Ochrony Pogranicza 1924-1939. Wybór dokumentów, wstęp M. Jabłonowski, wybór i oprac. M. Jabłonowski W. Janowski, B. Polak, J. Prochwicz, Warszawa-Pułtusk 2001.

Rocznik oficerski 1928, Warszawa 1928.

Wykaz duchowieństwa wojskowego oraz parafii, kościołów i kaplic wojskowych wyznania katolickiego w Rzeczypospolitej Polskiej na 1930 r., Warszawa 1930.

\section{Opracowania}

Ajnenkiel A., Geneza KOP - uwarunkowania polityczne [w:] Korpus Ochrony Pogranicza w 70 rocznicę powołania, red. L. Grochowski, Kętrzyn 1994.

Ciapka J., Zarys historii wojennej 33-go pułku piechoty, Warszawa 1929.

Cichoracki P., Stołpce-Łowcza-Leśna 1924. II Rzeczypospolita wobec najpoważniejszych incydentów zbrojnych w województwach pótnocno-wschodnich, Łomianki 2012.

Dominiczak H., Granice państwa i ich ochrona na przestrzeni dziejów 966-1996, Warszawa 1997.

Korpus Ochrony Pogranicza w czwarta rocznicę objęcia służby na granicach Rzeczypospolitej 1927-1928, Warszawa [1928].

Korpus Ochrony Pogranicza w druga rocznice objęcia służby na granicach Rzeczypospolitej 1925-1926, [Warszawa 1926].

Korpus Ochrony Pogranicza w trzecia rocznicę objęcia służby na granicach Rzeczypospolitej 1926-1927, red. F. Jamka-Koperski, Warszawa [1927].

Ochał A., Stużba zdrowia Korpusu Ochrony Pogranicza (1924-1939). Lekarze i sanitariusze w stużbie żotnierzy i ludności kresowej II Rzeczypospolitej [w:] Medycy polskiego pogranicza II Rzeczypospolitej 1918-1939, red. B. Urbanek, Warszawa 2018.

Pepłoński A., Wywiad polski na ZSRR 1921-1939, Warszawa 1996.

Sierpowski S., Źródła do historii powszechnej okresu międzywojennego, 1917-1926, Poznań 1989. 
Skubisz P., Psy meldunkowo-śledcze w służbie Korpusu Ochrony Pogranicza w latach 1924-1939, „Biuletyn Centralnego Ośrodka Szkolenia Straży Granicznej w Koszalinie" 2006, nr 1.

Zestawienie statystyczne wypadków zaszłych na terenie 1-6 brygady Korpusu Ochrony Pogranicza za czas od 1 października 1926 r. do 1 listopada 1926 r., Korpus Ochrony Pogranicza w druga rocznicę objęcia służby na granicach Rzeczypospolitej 1925-1926, Warszawa 1926.

Zestawienie statystyczne wypadków zaszłych na terenie 1-6 brygady Korpusu Ochrony Pogranicza za czas od 1 listopada 1926 r. do 1 listopada 1927 r., Korpus Ochrony Pogranicza w trzecia rocznicę objęcia służby na granicach Rzeczypospolitej 1926-1927, Warszawa 1927.

\section{Prace niepublikowane:}

Olejnik K., „Recenzja dysertacji doktorskiej. Artur Ochał, Brygada Korpusu Ochrony Pogranicza «Grodno» w latach 1929-1939, Szczecin, 2012”, Kołobrzeg 4 IV 2012, mps.

Skubisz P., „Wileńska Brygada Korpusu Ochrony Pogranicza w latach 1924-1937”, Szczecin 2008, mps.

\section{Prasa}

„Polska Zbrojna”, 13 XII 1927 r., nr 341.

„Szofer Polski. Dwutygodnik ilustrowany ogólno-autobusowy”, 1 IV 1927 r., nr 7.

\section{Internet}

Indeks represjonowanych IPN, https://indeksrepresjonowanych.pl/ (dostęp 10 II 2020 r.).

Kędziora A., Ostrowski Bronisław, zamosciopedia.pl (dostęp 20 II 2020 r.). Kędziora A., Zamościopedia, zamosciopedia.pl (dostęp 20 II 2020 r.).

\section{STRESZCZENIE}

\section{Artur Ochał, Bohaterski czyn por. Kazimierza Śledzińskiego podczas napadu pod Sieniawką (1926 r.). Przyczynek do historii Korpusu Ochrony Pogranicza (1924-1939)}

Kresy Wschodnie II Rzeczypospolitej, pomimo zawarcia traktatu pokojowego w Rydze (21 marca 1921 r.) formalnie kończącego wojnę polsko-rosyjską (1918-1921), nadal nie były miejscem bezpiecznym dla mieszkańców. Wprawdzie Rosja Radziecka oficjalnie uznała postanowienia traktatu pokojowego i ratyfikowała je, tym samym uznając m.in. kształt i przebieg granicy z Polską, ale komuniści związani z Międzynarodówką Komunistyczną nigdy nie zarzucili planów światowej rewolucji i przeniesienia jej płomienia poprzez Polskę do krajów Europy Zachodniej.

Zadaniem Korpusu Ochrony Pogranicza (KOP), jako specjalnej formacji wojskowej, utworzonej jesienią 1924 r. dla ochrony granic wschodnich państwa 
polskiego, było przywrócenie ładu, porządku i bezpieczeństwa na pograniczu w związku z dywersją i pospolitym bandytyzmem inspirowanym przez wywiad Związku Sowieckiego. Przyjęte przez dowództwo KOP ugrupowanie jednostek w trzech liniach, wspartych pododdziałami kawalerii, a przede wszystkim determinacja i stanowczość żołnierzy w zwalczaniu dywersji i bandytyzmu, miały doprowadzić do pacyfikacji band i uspokojenia sytuacji na pograniczu polsko-radzieckim.

W styczniu 1926 r. doszło do bandyckiego napadu na podróżnych autobusu pod Sieniawką na Nowogródczyźnie. Jednym z podróżnych był por. Kazimierz Śledziński, oficer 9 Batalionu KOP w Klecku, który w poczuciu żołnierskiego obowiązku w pojedynkę stoczył walkę z dywersantami w obronie osób cywilnych. Pomimo przewagi napastników zdołał odeprzeć atak - nie zważając na własne rany - wezwać pomoc. Był pierwszym żołnierzem, który został odznaczony Krzyżem Zasługi za Dzielność ustanowionym w 1928 r.

Słowa kluczowe: polskie formacje graniczne, II Rzeczypospolita Polska, Korpus Ochrony Pogranicza, radziecka dywersja

\section{SUMMARY}

\section{A rtur Ocha1, Lieutenant Kazimierz Śledziński's Heroic Act during the Ambush near Sieniawka (1926). Contribution to the History of the Border Protection Corps (1924-1939)}

Despite the signing of the peace treaty in Riga (March 21, 1921), which formally ended the Polish-Soviet War (1918-1921), the Eastern Borderlands of the Second Polish Republic were still not a safe place. Although Soviet Russia officially recognized the provisions of the peace treaty and ratified them - thus recognizing, among others, the shape and course of the border with Poland - the communists connected with the Communist International never abandoned their plans for a global revolution and carrying its flame through Poland to Western Europe.

The task of the Border Protection Corps (Korpus Ochrony Pogranicza, KOP), a special military formation created in the fall of 1924 to protect the eastern borders of the Polish state, was to restore order and security on the border in response to the diversion and common banditry inspired by Soviet intelligence. The grouping of units in three lines, supported by cavalry subunits, adopted by the KOP command, and above all the determination and firmness of the soldiers in fighting sabotage and banditry, was supposed to pacify the bands and calm the situation on the Polish-Soviet border.

In January 1926 there was a bandit attack on bus passengers near Sieniawka in Nowogródczyzna. One of the passengers was Lieutenant Kazimierz Śledziński, an officer of the 9th KOP Battalion in Klecko, who, with a sense of soldierly duty, fought alone against infiltraitors in defense of the civilians. Despite being outnumbered, 
he managed to repel the attack and bring help despite his wounds. He was the first soldier to be awarded the Cross of Merit for Bravery established in 1928.

Keywords: Polish border formations, Second Polish Republic, Border Protection Corps, Soviet diversion

\section{АННОТАЦИЯ}

\section{Артур Охал, Геройский поступок пор. Казимира Следзинского во время под Сенявкой (1926 г.). Вклад в историю Корпуса охраны пограничья (1924-1939)}

Восточные окраины Второй Речи Посполитой, несмотря на заключение мирного договора в Риге (21 марта 1921 г.), официально положившего конец польско-русской войне (1918-1921 гг.), все еще не были безопасным местом для ее жителей. Правда, Советская Россия официально признала и ратифицировала положения мирного договора, признав, в частности, форму и расположение границы с Польшей, но коммунисты, связанные с Коммунистическим Интернационалом, никогда не отказывались от своих планов мировой революции и переноса ее пламени через Польшу в страны Западной Европы.

Задача Корпуса охраны пограничья (КОП) как специального военного формирования, созданного осенью 1924 года для защиты восточных границ Польши, заключалась в восстановлении порядка и безопасности в приграничных районах в связи с подрывной деятельностью и обыкновенным бандитизмом, подстрекаемым разведкой Советского Союза. Принятая командованием КОП группировка военных подразделений в три линии, поддерживаемые кавалерийскими подразделениями, и, прежде всего, решимость и стойкость солдат в борьбе с диверсиями и бандитизмом должны были привести к успокоению беспорядков и урегулированию ситуации на польско-советской границе.

В январе 1926 г. случилось бандитское нападение на пассажиров автобуса под Сенявкой в районе Новогрудка. Одним из пассажиров был лейтенант Казимеж Следзинский, офицер 9-го батальона КОП в Клецке, который из чувства своего солдатского долга в одиночку сражался с саботажниками, защищая мирных жителей. При всем преимуществе нападающих, ему все же удалось отбить атаку и, несмотря на ранения, вызвать помощь. Он был первым солдатом, награжденным Крестом Заслуги „За Храбрость”, учрежденным в 1928 г.

Ключевые слова: польские пограничные формирования, Вторая Речь Посполитая, Корпус Охраны Пограничья, советская диверсия 